\title{
IMPLEMENTASI FUNGSI BADAN PERMUSYAWARATAN DESA (BPD) DALAM MEWUJUDKAN SUSTAINABLE DEVELOPMENT GOALS (SDGS) DESA
}

\author{
I Wayan Sutrisna \\ Fakultas Ilmu Sosial dan Ilmu Politik Univ. Mahendradatta \\ e-mail : sutrisna76@yahoo.co.id
}

\begin{abstract}
Abstrak - Paradigma pembangunan desa saat ini mengalami perubahan yang semakin cepat, sehingga dibutuhkan aparatur pemerintah desa yang benar-benar dapat menyesuaikan dengan keadaan yang terus berubah. Pemerintahan saat ini memberikan perhatian yang sangat serius dalam usaha mengurangi tingkat kemiskinan di desa. Hal ini dilakukan karena dengan pembangunan desa secara berkelanjutan akan memberikan maanfaat pada peningkatan perekonomian masyarakat, sehingga berdampak pada peningkatan kesejahteraan masyarakat.

Partisipasi masyarakat dalam proses pembangunan merupakan kunci utama suksesnya pelaksanaaan pembangunan karena menempatkan masyarakat sebagai motor penggerak atau sebagai subyek pembangunan bukan hanya sebagai obyek. Pembangunan dengan pendekatan partisipatif membuat masyarakat merasa memiliki serta ikut bertanggungjawab terhadap setiap proses dan hasil-hasil pembangunan. Prioritas pembangunan desa saat ini sudah diarahkan menuju tujuan pembangunan yang berkelanjutan atau Sustainable Development Goals (SDGs).

BPD sebagai lembaga "parlemen" di desa memiliki posisi strategis dalam menciptakan proses demokratisasi serta menjadi ujung tombak suksesnya pembangunan. BPD harus dimaksimalkan perannya dalam mewujudkan pola pembangunan yang partisipatif dengan merancang pembangunan yang betul-betul merupakan kehendak masyarakat. Tulisan ini bertujuan untuk mengkaji tentang implementasi fungsi Badan Permusyawaratan Desa (BPD) dalam mewujudkan Sustainable Development Goals (SDGs) Desa. Kajian ini menggunakan pendekatan studi literasi.
\end{abstract}

Kata kunci: desa, BPD, pembangunan berkelanjutan

\begin{abstract}
The paradigm of village development is changing rapidly, so it needs the village government apparatus that can really adjust to the changing situation. The current government is paying very serious attention in efforts to reduce poverty in the village. This is done because with sustainable village development will provide benefits to improve the economy of the community, thereby impacting on improving the welfare of the community.
\end{abstract}

Community participation in the development process is the main key to successful development implementation because it places the community as the driving force or as the subject of development not just as an object. Development with a participatory approach 
makes the community feel responsible for every process and results of development. The priority of village development has now been directed towards sustainable development goals (SDGs).

BPD as a "parliamentary" institution in the village has a strategic position in creating the democratization process as well as being the spearhead of successful development. BPD must maximize its role in realizing participatory development patterns by designing development that is really the will of the community. This paper aims to examine the implementation of the functions of the Village Consultative Agency (BPD) in realizing the Village Sustainable Development Goals (SDGs). This study uses a literacy study approach.

Keywords: village, BPD, sustainable development

\section{PENDAHULUAN}

Proklamasi Kemerdekaan Indonesia yang dibacakan oleh Sukarno atas nama Bangsa Indonesia pada tanggal 17 Agustus 1945 merupakan jembatan emas menuju kesejahteraan masyarakat Indonesia. Sejak saat itu Bangsa Indonesia terus berusaha mewujudkan tujuan nasional yang dicitacitakan oleh Bangsa Indonesia. Tujuan Nasional yang ingin diwujudkan oleh Bangsa Indonesia seperti tercantum dalam pembukaaan Undang-Undang Dasar 1945 alinea IV yaitu melindungi segenap bangsa Indonesia dan seluruh tumpah darah Indonesia dan untuk memajukan kesejahteraan umum, mencerdaskan kehidupan bangsa, dan ikut melaksanakan ketertiban dunia yang berdasarkan kemerdekaan, perdamaian abadi dan keadilan sosial. Dalam mewujudkan citacita dan tujuan nasional terdapat tiga faktor yang mempengaruhi yakni, kondisi geografis negara, manusia dan lingkungannya (Santosa, 2017).

Sasaran pembangunan yang dilaksanakan oleh Bangsa Indonesia adalah terwujudnya masyarakat Indonesia yang demokratis, karena dengan keadaan lebih demokratis memungkinkan masyarakat lebih terbuka untuk berpartisipasi dalam pembangunan di segala bidang. Menurut Siagian (1983), pembangunan merupakan suatu usaha atau rangkaian usaha pertumbuhan dan perubahan yang berencana dilakukan secara sadar oleh suatu bangsa, negara dan pemerintah, menuju modernitas dalam rangka pembinaaan bangsa (Nation-Building). Sementara, Hakim (2011) mengungkapkan bahwa paradigma pembangunan manusia sebagai konsep yang holistik, mempunyai empat unsur penting, yakni (1) peningkatan produktivitas; (2) pemerataan kesempatan; (3) kesinambungan pembangunan; (4) pemberdayaan masyarakat.

Perubahan yang sangat nyata dalam sistem ketatanegaraan Indonesia terjadi pada era reformasi yakni pada tahun 1998 yang mengubah pola pembangunan dari yang sangat sentralistik ke arah desentralisasi. Kebijakan desentralisasi dengan pemberlakuan otonomi daerah dilaksanakan secara progresif sejak tahun 2001. Perubahan arah kebijakan ini memberikan ruang yang lebih luas kepada daerah untuk menetukan arah kebijakan yang berbasis kearifan lokal. Pemberian wewenang kepada daerah diharapkan menjadi motivasi kepada seluruh 
komponen masyarakat di daerah untuk ikut serta berpartisipasi dalam seluruh proses pembangunan yang dilaksanakan oleh pemerintah. Partisipasi ini akan mampu menjadi kekuatan yang luar biasa dalam mensukseskan pembangunan itu sendiri. Dengan kebijakan Pemerintah yang memberikan keleluasaan kepada daerah untuk mengelola potensi daerahnya, pemerintah Kabupaten/Kota sebagaidaerah otonom saat ini berusaha menggalakan pembangunan partisipatif utamanya pada wilayah Desa.

Saat ini tuntutan masyarakat mengenai pelayanan kepada masyarakat merupakan faktor yang penting dalam penyelenggaraan pemerintah di Desa, partisipasi masyarakat merupakan faktor penentu yang perlu diperhatikan dalam melaksanakan pembangunan di Desa. Paradigma pembangunan desa saat ini mengalami perubahan yang semakin cepat, sehingga dibutuhkan para aparatur pemerintah desa yang benar-benar dapat menyesuaikan dengan keadaan yang terus berubah. Tingkat demokrasi di desa sangat menentukan keberhasilan pembangunan yang dilaksanakan. Badan Permusyawaratan Desa (BPD) sebagai lembaga legislatif di desa harus mampu menjadi pilar demokrasi dan pembangunan di desa. Pemberlakuan Undang Undang Nomor 6 Tahun 2014 tentang Desa makin memperjelas posisi desa dalam tatanan kehidupan berbangsa dan bernegara karena desa langsung ditata oleh pemerintah pusat melalui kementrian khusus yang menangani desa.

Pengertian desa yang tercantum dalam Undang-Undang Nomor 6 Tahun 2014 yakni desa dan desa adat atau yang disebut dengan nama lain, selanjutnya disebut Desa, adalah kesatuan masyarakat hukum yang memiliki batas wilayah yang berwenang untuk mengatur dan mengurus urusan pemerintahan, kepentingan masyarakat setempat berdasarkan prakarsa masyarakat, hak asal usul, dan/atau hak tradisional yang diakui dan dihormati dalam sistem pemerintahan Negara Kesatuan Republik Indonesia. Dengan adanya regulasi terbaru tentang desa maka negara mengamanatkan adanya alokasi dana dari Anggaran Pendapatan dan Belanja Negara (APBN) serta Anggaran Pendapatan dan Belanja Daerah (APBD) yang cukup untuk pembangunan di desa dengan harapan mampu menjadikan desa sebagai subyek pembangunan. Peningkatan pembangunan infrastruktur di Desa akan mampu meningkatkan kesejahteraan masyarakat terutama semakin cepatnya hasil-hasil pertanian dan produksi dari Desa terserap di pasaran khusunya di kota.

Badan Pusat Statistik (BPS) merilis bahwa pada tahun 2018 jumlah Desa yang ada di Indonesia adalah sebanyak 83.931. Secara geografis desa digolongkan menjadi dua yakni Desa yang terletak di tepi laut dan Desa yang terletak bukan di tepi laut. Membangun Desa berarti membangun Indonesia secara merata dan berkeadilan serta akan mampu menurunkan tingkat kemiskinan secara umum karena tingkat kemiskinan di Desa lebih tinggi dari pada di kota. Republika.co.id pada tanggal 15 Jnauari 2019 memuat informasi yang bersumber dari BPS menyebutkan bahwa persentase penduduk miskin antara di Kota dan Desa pada tahun 2018 adalah sebanyak 13,1\% masyarakat miskin tinggal di Desa dan $6,89 \%$ ada di Kota. 
Pemerintah terus berupaya menekan jumlah masyarakat miskin utamanya yang ada di daerah perdesaan. Alokasi APBN telah dikucurkan untuk membantu pemerintah Desa dalam upaya pemberdayaan masyarakat agar mampu keluar dari garis kemiskinan. Prioritas penggunaan dana desa yang dikucurkan pemerintah pusat sesuai dengan amanat Undang-Undang ditujukan untuk pembangunan berkelanjutan atau Sustainable Development Goals (SDGs) Desa. Dalam Peraturan Menteri Desa, Pembangunan Daerah Tertinggal, dan Transmigrasi Republik Indonesia Nomor 13 Tahun 2020 Tentang Prioritas Penggunaan Dana Desa Tahun 2021, disebutkan bahwa SDGs Desa adalah upaya terpadu mewujudkan Desa tanpa kemiskinan dan kelaparan, Desa ekonomi tumbuh merata, Desa peduli kesehatan, Desa peduli lingkungan, Desa peduli pendidikan, Desa ramah perempuan, Desa berjejaring, dan Desa tanggap budaya untuk percepatan pencapaian Tujuan Pembangunan Berkelanjutan.

Tulisan ini bertujuan untuk mengkaji tentang implementasi fungsi Badan Permusyawaratan Desa (BPD) dalam mewujudkan Sustainable Development Goals (SDGs) Desa. Kajian ini menggunakan pendekatan studi literasi.

\section{PEMBAHASAN}

\section{Membangun Indonesia dari desa}

Pemerintahan saat ini memberikan perhatian yang sangat serius dalam usaha untuk mengurangi tingkat kemiskinan di desa. Hal ini dilakukan karena dengan pembangunan desa secara berkelanjutan akan memberikan maanfaat pada peningkatan perekonomian masyarakat, sehingga berdampak pada peningkatan kesejahteraan mayoritas masyarakat Indonesia. Saat ini, mayoritas masyarakat miskin di Indonesia tinggal di desa-desa dengan permasalahan ekonomi yang beragam. Pemerintah memberikan solusi dengan kucuran dana dari APBN yang dapat dimanfaatkan oleh masyarakat desa dalam proses pembangunan berkelanjutan sesuai dengan kondisi desa masing-masing.

Presiden Joko Widodo bahkan memasukkan agenda pembangunan desa menjadi salah satu prioritas pemerintahannya. Nawa Cita yang diusung oleh Presiden Jokowi merupakan program untuk menunjukkan prioritas jalan perubahan menuju Indonesia yang berdaulat secara politik, serta mandiri dalam bidang ekonomi dan berkepribadian dalam kebudayaan. Salah satu program yang menjadi prioritas dalam Nawa Cita adalah membangun Indonesia dari pinggiran dengan memperkuat daerahdaerah dan desa dalam kerangka negara kesatuan. Dengan memberikan fokus pembangunan di tingkat desa diharapkan dapat mengurangi pergeseran Sumber Daya Manusia (SDM) yang berkualitas di desa menuju ke kota. Penduduk desa diberikan ruang yang luas dalam melaksankan pembangunan di desanya sesuai dengan keinginan mayoritas masyarakat.

Undang-Undang Nomor 6 tahun 2014 tentang Desa mewajibkan desa diatur agar menjadi kuat, maju, mandiri, dan demokratis sehingga tercipta landasan yang ideal dalam melaksanakan pemerintahan dan pembangunan desa menuju masyarakat yang sejahtera. Tujuan dari pengaturan desa adalah : 
a. Memberikan pengakuan dan penghormatan atas Desa yang sudah ada dengan keberagamannya sebelum dan sesudah terbentuknya Negara Kesatuan Republik Indonesia;

b. Memberikan kejelasan status dan kepastian hukum atas Desa dalam sistem ketatanegaraan Republik Indonesia demi mewujudkan keadilan bagi seluruh rakyat Indonesia;

c. Melestarikan dan memajukan adat, tradisi, dan budaya masyarakat Desa;

d. Mendorong prakarsa, gerakan, dan partisipasi masyarakat Desa untuk pengembangan potensi dan Aset Desa guna kesejahteraan bersama;

e. Membentuk Pemerintahan Desa yang profesional, efisien dan efektif, terbuka, serta bertanggung jawab;

f. Meningkatkan pelayanan publik bagi warga masyarakat Desa guna mempercepat perwujudan kesejahteraan umum;

g. Meningkatkan ketahanan sosial budaya masyarakat Desa guna mewujudkan masyarakat Desa yang mampu memelihara kesatuan sosial sebagai bagian dari ketahanan nasional;

h. Memajukan perekonomian masyarakat Desa serta mengatasi kesenjangan pembangunan nasional; dan

i. Memperkuat masyarakat Desa sebagai subjek pembangunan.

Kucuran dana dari APBN yang cukup besar ditujukan langsung kepada pemerintah desa telah mengubah paradigma pembangunan di desa yang sebelumnya hanya sebagai obyek pembangunan kini desa telah menjadi subyek pembangunan sehingga proses dan hasil pembangunan di desa betul-betul bermanfaat bagi masyarakat desa. Kendala yang dihadapi dalam proses pembangunan di desa adalah masih rendahnya kualitas sumber daya manusia di desa. permasalahan ini akan dapat diatasi dengan berbagai program dan kebijakan dari pemerintah seperti program sarjana membangun desa. Program ini akan mampu mengatasi kekurangan tenaga trampil dan terdidik di desa. Selain itu pelibatan institusi perguruan tinggi dalam membangun desa perlu ditingkatkan sehingga desa mandiri dapat diwujudkan.

Desa mandiri merupakan desa yang mampu memenuhi kebutuhannya dan apabila terdapat bantuan dari Pemerintah, bantuan tersebut hanya bersifat stimulus. Terdapat tiga sektor yang menjadi fokus dalam usaha realisasi kemandirian sebuah desa, yakni: (a) potensi ekonomi; (b) potensi sosial; dan (c) potensi Sumber Daya Manusia (Nursetiawan, 2018). Sementara Sidik (2015) menyebutkan bahwa kemandirian desa dimaknai sebagai upaya yang dilakukan oleh warga setempat melalui kapasitas institusi pemerintah desa dan emansipasi warga agar mampu mendayagunakan kemampuan, prakarsa/inisiatif dan gerakan desa secara kolektif dalam mengembangkan potensi/aset yang dimiliki baik fisik maupun nonfisik. Pemerintah desa harus mampu mengelola aset dan potensi yang dimiliki untuk dimanfaatkan menjadi peluang dalam pengelolaan pembangunan menuju kesejahteraan warga desa. Sebagai 
daerah otonom, Pemerintah Desa memiliki hak untuk mengelola potensi desanya yang ditujukan untuk kemakmuran masyarakat desa setempat. Dengan melaksanakan pembangunan dari desa diyakini akan mampu menekan jumlah penduduk miskin di Indonesia karena saat ini mayoritas penduduk miskin terdapat di desa. Membangun desa akan menciptakan pembangunan nasional terasa merata dan berkeadilan. Dengan keberadaan desa yang mandiri dan maju akan terwuju masyarakat Indonesia yang sejahtera, makmur dan berkeadilan.

\section{Partisipasi Masyarakat sebagai kekuatan utama Pembangunan}

Pembangunan yang dilaksanakan oleh pemerintah perlu didukung oleh seluruh komponen masyarakat. Sesuai data BPS tahun 2019 jumlah penduduk Indonesia berjumlah lebih dari 260 juta jiwa. Jumlah penduduk yang besar ini akan dapat menjadi kekuatan yang luar biasa dalam proses pelaksanaan pembangunan apabila seluruh masyarakat mau berpartisipasi dalam setiap proses pembangunan yang dilaksanakan. Sumber daya manusia yang dimiliki ini apabila diarahkan dengan optimal akan mampu menjadi kekuatan utama pendukung pembangunan nasional. Namun keberadaan penduduk yang banyak ini kadang juga merupakan hambatan yang sangat mengganggu proses pembangunan. Penduduk yang acuh tak acuh dan tidak peduli dengan kehidupan berbangsa dan bernegara akan menjadi hambatan dalam pembangunan ini.

Partisipasi masyarakat dalamproses pembangunan nasional merupak kunci utama suksesnya pelaksanaaan pembangunan karena akan menempatkan masyarakat sebagai motor penggerak atau sebagai subyek pembangunan bukan hanya sebagai obyek atau penerima manfaat saja. Pembangunan dengan pendekatan partisipatif membuat masyarakat merasa memiliki serta ikut bertanggungjawab terhadap setiap proses dan hasil-hasil pembangunan. Dalam Undang-Undang No. 25 Tahun 2004 tentang Sistem Perencanaan Pembangunan Nasional disebutkan bahwa, pendekatan partisipatif dalam penyusunan rencana pembangunan merupakan perencanaan dengan melibatkan semua pihak yang berkepentingan (stakeholders), pemangku kepentingan dilibatkan untuk mendapatkan aspirasi dan menciptakan rasa memiliki. Model partisipasi yang sifatnya masif (melibatkan masyarakat luas) sangat tepat diterapkan bagi perencanaan yang menyangkut kepentingan umum atau pembangunan yang berbasis wilayah (Lubis, 2009).

Pembangunan nasional dengan partisipasi masyarakat yang tinggi akan menghasilkan masyarakat yang semakin berdaya sehingga menjadi kekuatan yang mampu mewujudkan tujuan nasional sesuai yang di cita-citakan. Proses pelaksanaan pembangunan yang dilaksankan dengan pola partisifatif yakni pola pembangunan yang mulai dari proses perencanaan pada saat Musyawarah Perencanaan Pembangunan (Musrenbang) di tingkat desa sudah melibatkan seluruh komponen masyarakat secara partisifatif akan mampu mewujudkan pertumbuhan ekonomi yang tinggi dan berkualitas. Fadil (2013), menyebutkan bahwa keterlibatan aktif masyarakat dalam perencanaan pembangunan sangat penting dalam bentuk 
partisipasinya pada pelaksanaan Musrenbang. Semakin banyak masyarakat terlibat dalam Musrenbang akan membuat perencanaan pembangunan lebih aspiratif sehingga apa yang akan dikerjakan sesuai dengan keinginan mayoritas masyarakat setempat.

\section{Selama ini pelaksanaan}

Musrenbang di banyak desa belum mampu menghadirkan seluruh pemangku kepentingan, pelaksanaan perencanaan pembangunan ini hanya melibatkan segelintir elite yang ada di desa. Hal ini dapat diakibatkan oleh anggapan bahwa pelaksanaan Musrenbang hanya proses seremonial belaka sehingga masyarakat secara umum memiliki keengganan untuk melibatkan diri dalam kegiatan tersebut. Untuk meningkatkan partisipasi politik masyarakat desa, sangat diperlukan peranan dari Pemerintahan Desa yang keberadaannya adalah

berhadapan langsung dengan masyarakat. Pemerintahan Desa dapat memberikan penyuluhan-penyuluhan, pendidikan politik sehingga masyarakat desa akan mengerti dan memahami bahwa partisipasi mereka dalam politik dapat menunjang pembangunan desa ke arah yang lebih baik (Kusmanto, 2013). Sedangkan Deviyanti (2013), menyatakan bahwa partisipasi masyarakat dalam pembangunan ditentukan oleh kemauan masyarakat itu sendiri untuk melibatkan diri atau tidak dalam proses pembangunan yang dilaksanakan.

Undang-Undang No. 6 tahun 2014 tentang Desa mengamanatkan bahwa salah satu kewajiban masyarakat adalah berpartisipasi dalam setiap pembangunan yang dilaksankan. Partisipasi masyarakat akan mengarah kepada pemberdayaan masyarakat karena melalui partisipasi dalam seluruh proses, masyarakat akan semakin berdaya dan mampu mengendalikan proses tersebut kearah pencapaian kesejahteraan masyarakat itu sendiri. Pemberdayaan masyarakat dalam proses pembangunan mengandung arti bahwa masyarakat berinisiatif memulai proses kegiatan untuk perubahan kearah yang lebih baik. Pemberdayaan masyarakat hanya bisa terjadi apabila warganya ikut berpartisipasi. Partisipasi masyarakat merupakan modal utama dan kekuatan untuk mensukseskan pembangunan.

\section{Peran BPD dalam mewujudkan pembangunan berkelanjutan di desa}

Pembangunan yang dilaksanakan di desa sangat memerlukan partisipasi masyarakat agar sasaran dari pembangunan itu mampu meningkatkan kesejahteraan masyarakat. Dalam tatanan pemerintahan desa terdapat sebuah lembaga yang menjadi mitra pemerintah desa dalam menjalankan roda pemrintahan di desa yakni Badan Permusyawaratan Desa (BPD). Lembaga ini merupakan wadah bagi perwakilan masyarakat desa untuk mensukseskan pelaksanaan pembangunan yang dirancang bersama. Undang-Undang Nomor 6 Tahun 2014 menyebutkan, Badan Permusyawaratan Desa atau yang disebut dengan nama lain adalah lembaga yang melaksanakan fungsi pemerintahan yang anggotanya merupakan wakil dari penduduk Desa berdasarkan keterwakilan wilayah dan ditetapkan secara demokratis. BPD mempunyai fungsi yaitu, (1) membahas dan menyepakati Rancangan Peraturan Desa bersama Kepala Desa; (2) menampung dan menyalurkan aspirasi 
masyarakat Desa; dan (3) melakukan pengawasan kinerja Kepala Desa.

Pelaksanaan fungsi BPD dalam proses pemerintahan di desa membuat lembaga "parlemen" desa ini memiliki posisi yang strategis dalam menciptakan proses demokratisasi di desa serta menjadi ujung tombak suksesnya pembangunan. Menurut Sidik (2015), Pemerintahan Desa merupakan bagian dari mata rantai birokrasi negara yang menjalankan fungsi regulasi dan kontrol pada wilayah tersebut melalui pelayanan administratif, implementasi proyek-proyek pembangunan, mobilisasi masyarakat untuk mendukung kebijakan pemerintah dalam melakukan pelayanan bagi warganya di desa. Suksesnya pembangunan di desa sangat ditentukan oleh tingkat partisipasi masyarakat dalam perencanaan, pelaksanaan dan evaluasi proses pembanguna yang dilaksanakan. BPD sebagai lembaga perwakilan desa harus memberikan ruang yang luas kepada masyarakat untuk terlibat dalam seluruh proses pemerintahan yang dijalankan serta aktif dalam penyerapan aspirasi guna mewujudkan pembangunan partisipatif.

Peran BPD sebagai unsur penyelenggaran pemerintahan desa memiliki posisi yang strategis dalam menjawab kebutuhan masyarakat sesuai dengan situasi dan kondisi masyarakat setempat (Roza dan Arliman, 2017). BPD harus mampu mengarahkan manajemen pembangunan yang dilaksanakan di desa menuju kepada peningkatan kesejahteraan masyarakat dengan pendekatan partisipatif. Selain itu BPD harus mengawal agar proses pemerintahan di desa dapat dilakukan secara transparan melalui prinsip open government dan e-government sehingga masyarakat mampu memberikan pengawasan serta masukan demi kemajuan pembangunan di desa mereka. Yamin, et.al (2019) mengungkapkan bahwa Inovasi dan teknologi yang digunakan oleh pemerintahan menjadi pendorong pada pendekatan yang lebih holistik atau menyeluruh serta dapat menyelesaikan masalah dengan melibatkan peran banyak aktor di dalamnya.

Prioritas pembangunan desa saat ini sudah diarahkan menuju tujuan pembangunan yang berkelanjutan atau Sustainable Development Goals (SDGs). Dalam Peraturan Menteri Desa, Pembangunan Daerah Tertinggal, dan Transmigrasi Republik Indonesia Nomor 13 Tahun 2020 Tentang Prioritas Penggunaan Dana Desa Tahun 2021, disebutkan bahwa SDGs Desa adalah upaya terpadu mewujudkan Desa tanpa kemiskinan dan kelaparan, Desa ekonomi tumbuh merata, Desa peduli kesehatan, Desa peduli lingkungan, Desa peduli pendidikan, Desa ramah perempuan, Desa berjejaring, dan Desa tanggap budaya untuk percepatan pencapaian Tujuan Pembangunan Berkelanjutan. Keberhasilan mewujudkan pembanguan yang berkelanjutan harus didukung oleh Pemberdayaan masyarakat secara maksimal.

BPD sebagai lembaga legeslatif desa harus mampu menyiapkan aturan yang mengarahkan pelaksanaan pembangunan dan pemerintahan sesuai dengan prinsipprinsip good governance. Pelaksanaan fungsi BPD hendaknya dimaksimalkan dalam mewujudkan pola pembangunan yang partisipatif. Aspirasi masyarakat yang 
diserap agar disalurkan dalam Musyawarah Desa (Musdes) sebagai wadah untuk merancang pembangunan yang betul-betul merupakan kehendak masyarakat. Pendekatan partisipatif akan memungkinkan masyarakat desa lebih berdaya sehingga pembangunan yang dilaksanakan dapat mengarah kepada terwujudnya pembangunan yang berkelanjutan.

\section{PENUTUP}

\section{Simpulan}

Sejak pemberlakuan UndangUndang Nomor 6 tahun 2014 tentang Desa, Proses pembangunan yang dilaksanakan di desa selain mendapatkan transfer dana dari pemerintah daerah juga dialokasikan dari APBN. Hal ini membuat desa bukan lagi hanya sebagai obyek tetapi sudah menjadi subyek pembangunan. Pembangunan yang dilaksanakan benar-benar sesuai dengan kebutuhan masyarakat dalam menunjang peningkatan perekenomian desa sehingga berdampak pada kesejahteraan masyarakat yang semakin baik. Pendekatan partisipatif menjadi hal yang harus dilakukan agar masyarakat semakin berdaya dalam setiap proses pembangunan yang dilaksanakan. Cerminan masyarakat berdaya adalah masyarakat yang proaktif dalam setiap proses serta menikmati hasil yang maksimal dari pembangunan yang dilaksanakan.

BPD sebagai lembaga "parlemen" di desa yang memiliki tiga fungsi yakni legeslasi, controlling dan menyerap aspirasi, memiliki posisi strategis dalam menciptakan proses demokratisasi di desa serta menjadi ujung tombak suksesnya pembangunan. BPD harus dimaksimalkan perannya dalam mewujudkan pola pembangunan yang partisipatif dengan merancang pembangunan yang betul-betul merupakan kehendak masyarakat. Partisipasi masyarakat yang tinggi dapat membuat masyarakat lebih berdaya sehingga perekonomian masyarakat tumbuh secara maksimal danpembangunan berkelanjutan yang tertuang dalam SDGs desa dapat diwujudkan.

\section{Rekomendasi}

Lembaga BPD selaku mitra kepala desa dalam proses pembangunan dan pemerintahan di desa harus didukung dengan pemahaman yang sama tentang visi-misi pemerintah desa menuju terwujudnya pembangunan berkelanjutan. Persamaan pemahaman ini dapat dilakukan dengan melakukan kegiatan bimbingan teknis atau kegiatan lainnya tentang pelaksanaan fungsi, hak dan kewajiban sebagai anggota BPD. Antara pemerintah desa (Kepala Desa bersama Perangkat Desa) dan BPD harus terjalin hubungan yang harmonis sehingga setiap proses pemerintahan dan pembangunan dapat dilakukan sesuai tufoksi masing-masing yang bermuara pada peningkatan kesejahteraan masyarakat serta terwujudnya tujuan yang ingin dicapai yakni pembangunan berkelanjutan.

\section{Daftar Pustaka}

Deviyanti, Dea. 2013. Studi Tentang Partisipasi Masyarakat dalam Pembangunan di Kelurahan Karang Jati Kecamatan Balikpapan Tengah. eJurnal Administrasi Negara 2013.1 (2). Hal 380-394. 
Fadil, Fathurrahman. 2013. Partisipasi Masyarakat dalam Musyawarah Perencanaan Pembangunan di Kelurahan Kotabaru Tengah. Jurnal Ilmu Politik dan Pemerintahan Lokal, Volume II Edisi 2. Hal. 251-262.

Hakim, Lukman EM. 2011. Pengantar Administrasi Pembangunan. Jogjakarta. Ar-Ruzz Media.

Kusmanto, Heri. 2013. Peran Badan Permusyawaratan Daerah dalam Meningkatkan Partisipasi Politik Masyarakat. Jurnal Ilmu Pemerintahan dan Sosial Politik 1 (1) (2013). Hal. 39-47

Lubis, Asri. 2009. Upaya Meningkatkan Partisipasi Masyarakat dalam Pembangunan. Jurnal Tabularasa. Vol.6 No.2, Desember 2009. Hal. 181-190

Nursetiawan, Irfan. 2018. Strategi Pengembangan Desa Mandiri melalui Inovasi BUMDes. Moderat: Jurnal Ilmiah Ilmu Pemerintahan Vol 4, No 2 (2018). Hal. 72-81.

Peraturan Menteri Desa, Pembangunan Daerah Tertinggal, dan Transmigrasi Republik Indonesia Nomor 13 Tahun 2020 Tentang Prioritas Penggunaan Dana Desa Tahun 2021

Roza, Darmini dan Arliman S, Laurensius. 2017. Peran Badan Permusyawaratan Desa di dalam Pembangunan Desa dan Pengawasan Keuangan Desa. Padjajaran Jurnal Ilmu Hukum Vol. 4 No. 3 Tahun 2017. Hal. 606-624.
Santosa, Pandji. 2017. Administrasi Publik; Teori dan Aplikasi Good Governance. Bandung. Refika Aditama.

Undang-Undang Dasar Republik Indonesia dan Perubahannya, (Amandemen I, II, III dan IV), Penabur Ilmu.

Undang-Undang Republik Indonesia Nomor 6 Tahun 2014 tentang Desa.

Undang-Undang Republik Indonesia Nomor 25 Tahun 2004 tentang Sistem Perencanaan Pembangunan Nasional.

Siagian. S. P. 1983, Administrasi Pembangunan : Konsep, Dimensi dan Strateginya, Jakarta, PT Gunung Agung.

Sidik, Fajar. 2015. Menggali Potensi Lokal Mewujudkan Kemandirian Desa. Jurnal Kebijakan \& Administrasi Publik. Vol 19 No 2 (2015). Hal. 115131.

Yamin, Muhammad., Darmawan, Arief Bakhtiar., Zayzda, Nurul Azizah., dan Ash-Shafikh, Maiza. 2019. Analisis Open Government dan eGovernment di Indonesia Berdasarkan Kerangka Kerja SDGs: Studi Kasus Desa Melung, Kabupaten Banyumas. Jurnal Hubungan Internasional Vol. 7, No.2 Oktober 2018 - Maret 2019. Hal. 133-142.

https://bps.go.id

https://republika.co.id 